Research Article

\title{
Creep Investigation on Shale-Like Material with Preexisting Fissure under Coupling Temperatures and Confining Pressures
}

\author{
Yongyan Wang $(\mathbb{D}$, Hongwei Wang $(\mathbb{D}$, and Xiao Shi \\ Qingdao University of Science and Technology, Qingdao 266061, China \\ Correspondence should be addressed to Hongwei Wang; 17606399387@163.com
}

Received 28 May 2019; Revised 5 August 2019; Accepted 27 August 2019; Published 29 September 2019

Academic Editor: Castorina S. Vieira

Copyright (c) 2019 Yongyan Wang et al. This is an open access article distributed under the Creative Commons Attribution License, which permits unrestricted use, distribution, and reproduction in any medium, provided the original work is properly cited.

\begin{abstract}
In order to investigate the influence of temperature, confining pressure, and preexisting fissure on creep characteristics of rock mass, multistage creep experiments were performed on shale-like material, with preexisting fissure under different temperatures and confining pressures. The results showed that new microcracks generated and propagated with the increase of temperature in both uniaxial and triaxial creep experiments, and the generation and propagation were most pronounced at $60^{\circ} \mathrm{C}$ and least at $20 \sim 50^{\circ} \mathrm{C}$ in uniaxial creep experiments. The generation and propagation were restricted by confining pressure. Temperature had less influence on the creep strain rate in triaxial creep experiment, whereas it had a significant influence on the steady-state creep rate in uniaxial creep experiment. The influence of confining pressure on the steady-state creep rate was slight when confining pressure was $1 \mathrm{MPa}$, whereas it was obvious when confining pressure was $3 \sim 7 \mathrm{MPa}$. The closure of preexisting fissure promoted the creep strain rate, and the closure was incomplete when confining pressure was below $3 \mathrm{MPa}$, whereas it was complete when confining pressure at 5 and $7 \mathrm{MPa}$.
\end{abstract}

\section{Introduction}

In recent years, the maximum mining depth in China has reached $1,500 \mathrm{~m}$ and the maximum mining depth of other countries has also reached over $1,000 \mathrm{~m}$. There are serious potential risks in the process of coal mining due to the deformation of surrounding rock roadway, especially the creep characteristics of shallow rock mass are quite different from those of deep rock mass, due to the environmental difference of high ground temperature and high ground stress. It is difficult to guide the deep geotechnical engineering practice effectively and scientifically with current rock mechanics theory [1]. Plenty of scholars have devoted their efforts to the study of rock mechanical property under different temperatures and confining pressures. Chen et al. [2] investigated the influence of temperature and stress conditions on granite's creep behavior; they found that the influence of temperature on granite's creep strain was slightwhen the temperature was below $90^{\circ} \mathrm{C}$, whereas the creep strain rate accelerated with the elevation in temperature and the influence was enhanced with the increase of confining pressure. Rybacki et al. [3] investigated the influence of elevated temperature and pressure on shale's creep characteristics, which found the strength decreased with temperature, whereas the creep strain increased with temperature. Lu and Wang [4] studied the influence of temperature on creep characteristics of coal measures mudstone, which found that the creep strain, creep duration time, and creep strain rate were increased with temperature. Heap et al. [5] found the strength of sandstones decreased with elevated temperature from $20^{\circ} \mathrm{C}$ to $75^{\circ} \mathrm{C}$. Nara et al. $[6,7]$ found the crack velocity of andesite increased with temperature. The crack velocity of Whin Sill dolerite and Crab Orchard sandstone increased with increasing temperature $[8,9]$. The creep strain rates in porous sandstones increased with elevated temperature in any given differential stress [10]. The failure mode of granite transformed from tensileshear compound failure to tensile failure with increasing temperature [11]. Zhang et al. [12] and Mishra and Verma et al. [13] investigated the creep characteristics of salt rocks and coal-measure shale rocks, respectively, which found the creep strain rates increased with deviatoric stress. Liu et al. 
[14] investigated the influence of deviatoric stress on the creep strain and creep strain rate of clay-rich rock, which found both the creep strain and creep strain rate increased with deviatoric stress and the permeability decreased obviously with elevated confining pressure. Zhang et al. $[15,16]$ carried out the multiloading creep tests on cataclastic rocks and found the time-dependent behavior decreased significantly with increasing confining pressure. Zhang et al. [17] found the creep strain increased with confining pressure in multistage creep test and the higher the confining pressure was, the lower the creep strain rate was in secondary creep. Nadimi et al. [18] investigated the creep characteristics of intact rocks from Siah Bisheh.

There were plenty of microcracks and fissures in rock mass, and both of them had a negative influence on the strength and long-term stability. Chao et al. [19] investigated the influence of fissure angle on the creep characteristics, which found the biggest deviatoric stress occurred when fissure angle was $90^{\circ}$ and the minimum deviatoric stress occurred when fissure angle was $30^{\circ}$. Zhipeng et al. [20] established a new anisotropic elasto-viscoplastic creep model, which applied to granite with fissure. Brantut et al. [21] investigated the influence of initial damage (porosity and crack) on the creep strain rate and they found the higher the initial damage was, the faster the creep strain rate was. Heap et al. [22] found the creep strain rate of volcano depended on both the mechanical property and the reduction in crack aperture. Yongyan et al. [23] investigated the influence of preexisting fissure angle on rock-like material's strength characteristics and found when the maximum fissure angle was $45^{\circ}$, that confining pressure exhibited the greatest influence on rock-like material's strength.

However, most of the previous investigations only considered the effect of a single factor or two factors combined among temperature, confining pressure, and preexisting fissure, whereas few of these studies took all three factors into consideration. The influence of high crustal stress, earth temperature, and fissure on deep rock mass was simultaneous; it was necessary to take temperature, confining pressure, and fissure into consideration during the creep experiment. Therefore, we investigated the influence of temperature and confining pressure on shale-like material with a preexisting fissure. Three types of creep experiment were carried on, which were coupling creep test of temperature and preexisting fissure, coupling creep test of confining pressure and preexisting fissure, and coupling creep test of temperature, confining pressure, and preexisting fissure.

\section{Experiments}

2.1. Specimen Preparation. The shale-like material, used in this article, was simulated for the shale in Tang Kou mining. The shale was black in color, compact, and had low hardness. Creep experiments of shale under different temperature had been carried out in our laboratory before [24]. We found the creep rate, for both shale and shale-like material, increased with elevated temperature and the creep behavior of shale and shale-like material was similar. The mechanical parameters of Tang Kou shale and shale-like material are shown in Table 1, and the creep strains and characteristics are shown in Table 2, which confirmed that the shale can be replaced by shale-like material.

The specimens of shale-like material were made of cement, river sand, water, and gesso. The mass ratio of cement, river sand, water, and gesso was $1: 2: 0.4: 0.36$. The grain size of river sand was between 20 and 40 mesh diameters. The specimen mould is shown in Figure 1. The preparation of specimens followed Standard for test methods of engineering rock mass (GB/T 50266-2013) [25]. The specimens were made with a length of $100 \mathrm{~mm}$ and diameter of $50 \mathrm{~mm}$. The nonparallelism error of two end faces of the specimen was controlled within $0.05 \mathrm{~mm}$, the diameter error was controlled within $0.3 \mathrm{~mm}$ along the height of the specimen, and the deviation of the end face to specimens' axis controlled within $0.25^{\circ}$. The fissure was located in the middle of the specimen and the fissure angle was $45^{\circ}$ angle along the bottom end face. The size of the preexisting fissure was $A=1 \mathrm{~mm}$ in width, $B=20 \mathrm{~mm}$ in length, and $C=35 \mathrm{~mm}$ in depth, which was explained in Figures 2 and 3 . The specimens were stored in a climatecontrolled environment to keep the uniformity of temperature, and humidity during drying and the drying time was 15 days.

2.2. Experimental Apparatus and Methodology. The specimens were dried in the temperature and humidity chamber (Figure 4), which can provide a constant temperature and humidity. Therefore, it was possible to ensure that all specimens could be at controlled temperature and relative humidity. The creep experiments were performed with TAW-200 material mechanics testing machine (Figure 5) in the Rheological Mechanics Laboratory at Qingdao University of Science and Technology.

Creep experiments were performed at different temperatures and confining pressures. The test temperatures varied from 20 to $60^{\circ} \mathrm{C}$, and confining pressures varied from 0 to $7 \mathrm{MPa}$. Specimens were wrapped with heat shrink tubing to protect specimens from silicone oil. Specimens were heated to objective temperature with electromagnetic heating coil and the temperature was kept for 1 hour before creep test to ensure the temperature of specimen was uniform inside and outside.

Multistage loading method was adopted in creep experiment because previous studies had proven that the discreteness of specimen's strength can be reduced with this method $[22,26]$. We tested the peak stress of shale-like material at different confining pressures. And, the axial stress of each step was determined based on the average peak stress at each kind of confining pressure; first, we chose the axial stress in the first step based on the average peak stress and the stress in the later step was equal to the interval loading, which meant the difference value between every two steps was equal. The axial stress in multistage loading of each step is shown in Table 3 . When the strain rate became stable $\left(d \varepsilon / d t<0.0005 \mathrm{~h}^{-1}\right)$, which meant the creep test under this level of stress was completed, the subsequent level of stress 
TABLE 1: Comparison table of parameters between shale-like material and Tang Kou shale.

\begin{tabular}{lccccc}
\hline Mechanical parameters & $\begin{array}{c}\text { Density } \\
\left(\mathrm{g} / \mathrm{cm}^{3}\right)\end{array}$ & $\begin{array}{c}\text { Young's modulus } \\
(\mathrm{GPa})\end{array}$ & $\begin{array}{c}\text { Compressive } \\
\text { strength }(\mathrm{MPa})\end{array}$ & $\begin{array}{c}\text { Internal friction } \\
\text { angle }\left({ }^{\circ}\right)\end{array}$ & $\begin{array}{c}\text { Cohesion force } \\
(\mathrm{MPa})\end{array}$ \\
\hline Parameters of Tang Kou shale $^{\mathrm{O}}$ & $1.8 \sim 2.0$ & $1.3 \sim 2.1$ & $10 \sim 20$ & $45 \sim 65$ & $3 \sim 20$ \\
Parameters of shale-like material $^{\mathrm{a}}$ & 1.902 & 1.864 & 12.077 & 32.751 & 4.199 \\
\hline
\end{tabular}

${ }^{a}$ Parameters of shale-like material are the average value from intact shale-like material's testing results.

Table 2: Comparison of the creep characteristics between Tang Kou shale and shale-like material.

\begin{tabular}{lcccc}
\hline Index & $\begin{array}{c}\text { Instantaneous } \\
\text { strain }\left(\times 10^{-3}\right)\end{array}$ & $\begin{array}{c}\text { Axial strain } \\
\left(\times 10^{-3}\right)\end{array}$ & $\begin{array}{c}\text { Influence of temperature } \\
\text { to creep rate }\end{array}$ & $\begin{array}{c}\text { Influence of confining pressure } \\
\text { to creep rate }\end{array}$ \\
\hline Tang Kou shale & $0.140 \sim 0.258$ & $0.32 \sim 1.52$ & Creep rate increases with temperature & Creep rate decreases with confining pressure \\
Shale-like material & $0.199 \sim 0.628$ & $0.30 \sim 1.62$ & Creep rate increases with temperature & Creep rate decreases with confining pressure \\
\hline
\end{tabular}

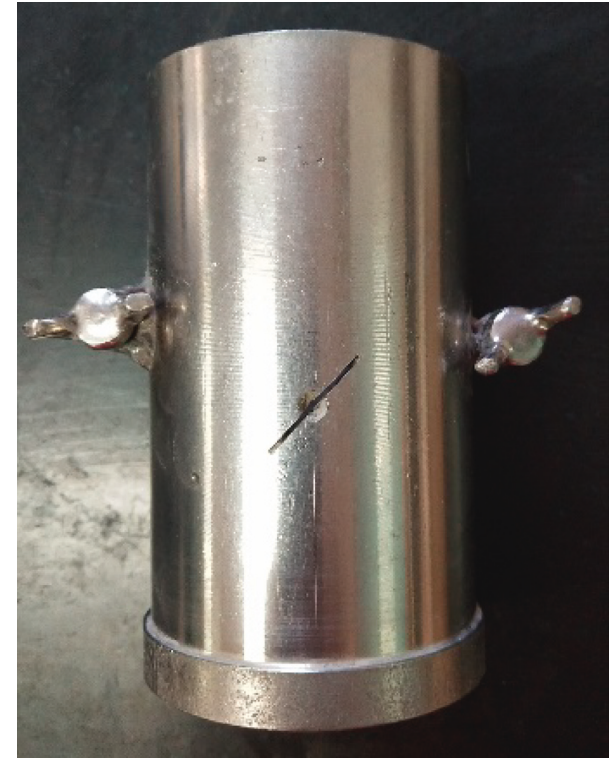

FIGURE 1: The mould of specimen.

can be applied, axial stress applied to the specimen until accelerated creep phase occurred or the specimen failure.

\section{Experiment Results and Discussion}

3.1. Axial Creep Experiment under Different Temperatures. The strain-time curves of uniaxial creep experiments under different temperatures are shown in Figure 6. We can see from Figure 6 that the curves, for both intact and fissure specimens, can be divided into three phases, which are primary creep phase, steady-state creep phase, and the accelerated creep phase. The axial strains in intact specimen are lower than those in fissure one, which is due to the closure of preexisting fissure. The axial strain increases with elevated temperature, and the higher the temperature, the faster the specimen failures. This is due to the elevated temperature contributes to the generation of new microcracks $[6,7,27]$. The accelerated creep phase occurs under the combined effect of temperature and axial stress. In Glove's investigation [27], the new thermal microcrack begins to generate at about $100^{\circ} \mathrm{C}$, which is different with our result. The reason of the difference is the specimen in their

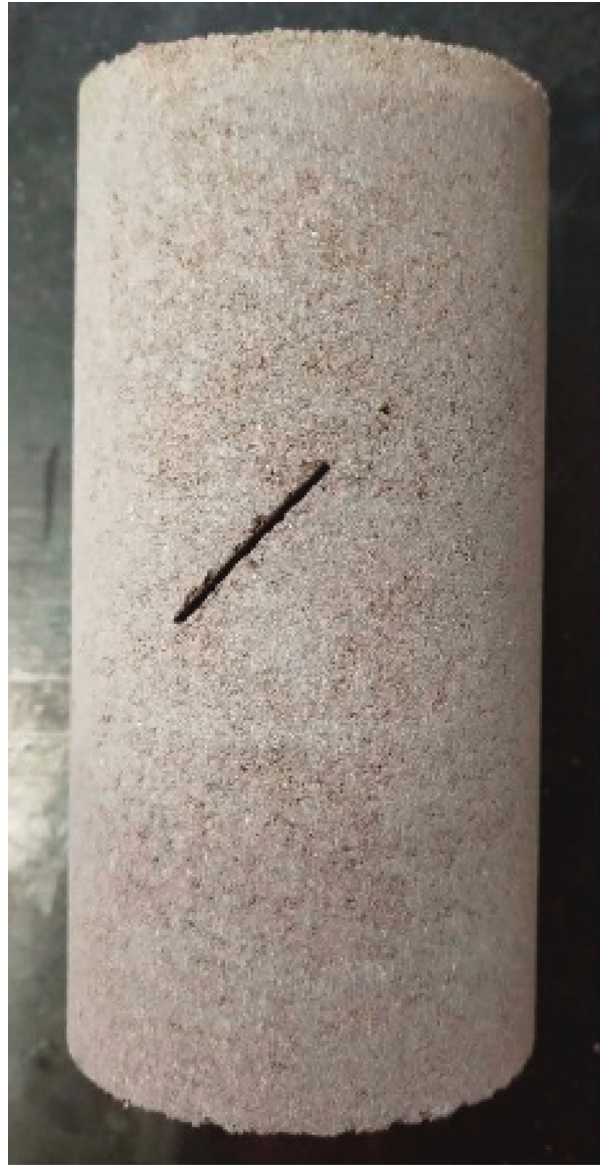

FIgURE 2: The prepared specimen.

test is granite, a kind of hard rock, whereas the specimen in our experiment is a shale-like material, a kind of soft rock. Therefore, the new microcracks generate at lower temperature in our investigation.

The steady-state creep rates at different temperatures are shown in Figure 7. The steady-state creep rate is smallest at $20^{\circ} \mathrm{C}$ and the value is $0.102 \times 10^{-3} / \mathrm{h}$; the steady-state creep rate increases with temperature, which confirms that elevated temperature contributes to the acceleration of creep. Nara et al. [6, 7] found that the crack velocity increased with elevated temperature in andesite. The creep strain rates of each creep stage are shown in Table 4 and interesting 


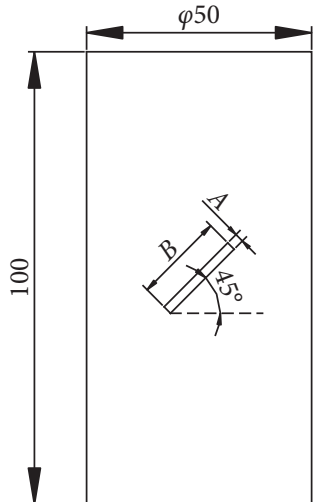

(a)

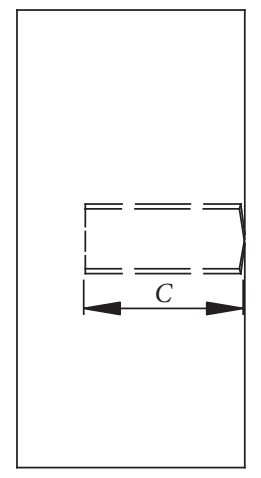

(b)

Figure 3: The schematic diagram of fissure. (a) Front view of specimen and (b) lateral view of specimen.

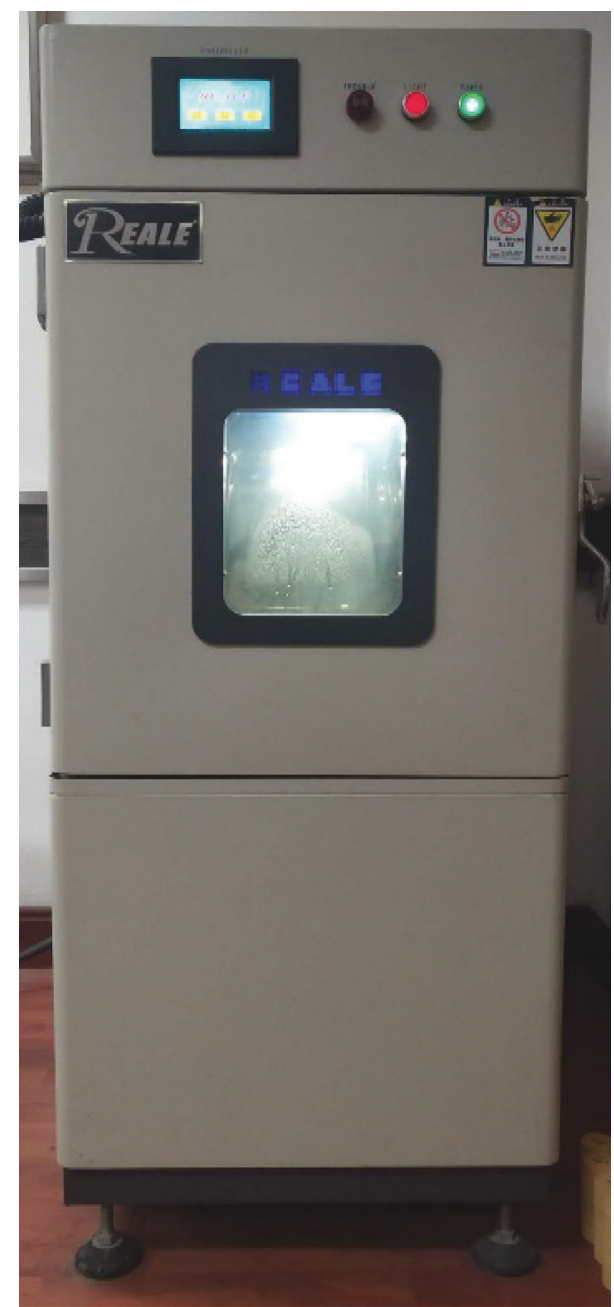

FIgURE 4: The temperature and humidity chamber.

phenomenons can be seen in Table 4 that (1) the biggest creep strain rates are in the first stage at all temperatures and (2) the creep strain rates in four stages of each specimen are similar in value at $60^{\circ} \mathrm{C}$. The reason of this phenomenon can be attributed to the influence of preexisting fissure. New microcracks generated by thermal expansion are few at

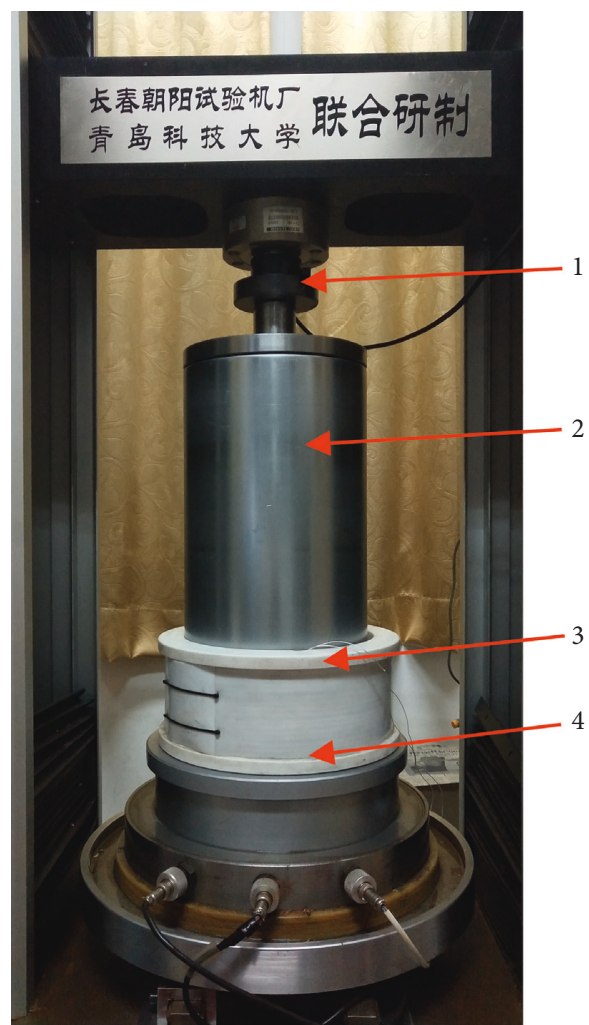

FIgURE 5: TAW-200 material mechanics testing machine. 1-stress loading device, 2-triaxial cell, 3-temperature sensor, and 4-electromagnetic heating.

$20 \sim 50^{\circ} \mathrm{C}$; moreover, the preexisting fissure closes in the first creep stage, which contributes to the acceleration of the creep strain rate in the first creep stage. The new microcracks generated by thermal expansion increases at $60^{\circ} \mathrm{C}$, and the influence of preexisting fissure on creep strain rate decreases. Therefore, the creep strain rate fluctuates in a very small range during $60^{\circ} \mathrm{C}$. The damaged specimen is shown in Figure 7 ; the cracks at $60^{\circ} \mathrm{C}$ are more than those at $20^{\circ} \mathrm{C}$. This may be due to the generation of new microcrack promoted by the higher temperature in specimens. Figure 7 shows the fitting curve of the steady-state creep rate at different 
TABLE 3: The axial stress of each loading grade under different confining pressures.

\begin{tabular}{lcccc}
\hline \multirow{2}{*}{ Confining pressure (MPa) } & \multicolumn{3}{c}{ Axial stress (MPa) } \\
& First step (45\% 55\%) & Second step (60\% 65\%) & Third step (75\% 80\%) & Fourth step (85\% 95\%) \\
\hline 0 & 3.06 & 4.08 & 5.10 & 6.11 \\
1 & 8.15 & 10.19 & 12.23 & 14.27 \\
3 & 12.23 & 15.29 & 18.34 & 21.40 \\
5 & 16.31 & 20.38 & 24.46 & 28.54 \\
7 & 22.42 & 28.54 & 34.65 & ${ }^{c}$ \\
\hline
\end{tabular}

${ }^{\mathrm{b}}$ The percentage means the ratio of axial stress of each stage against the strength (three specimens were tested at each kind of confining pressure) at each kind of confining pressure, for example, $45 \%$ 55\% means the value of axial stress against strength of the tested specimen at each kind of confining pressure varies from $45 \%$ to $55 \%$. The four steps means four loading grades. ${ }^{\circ}$ The Specimen had damaged before the fourth step.

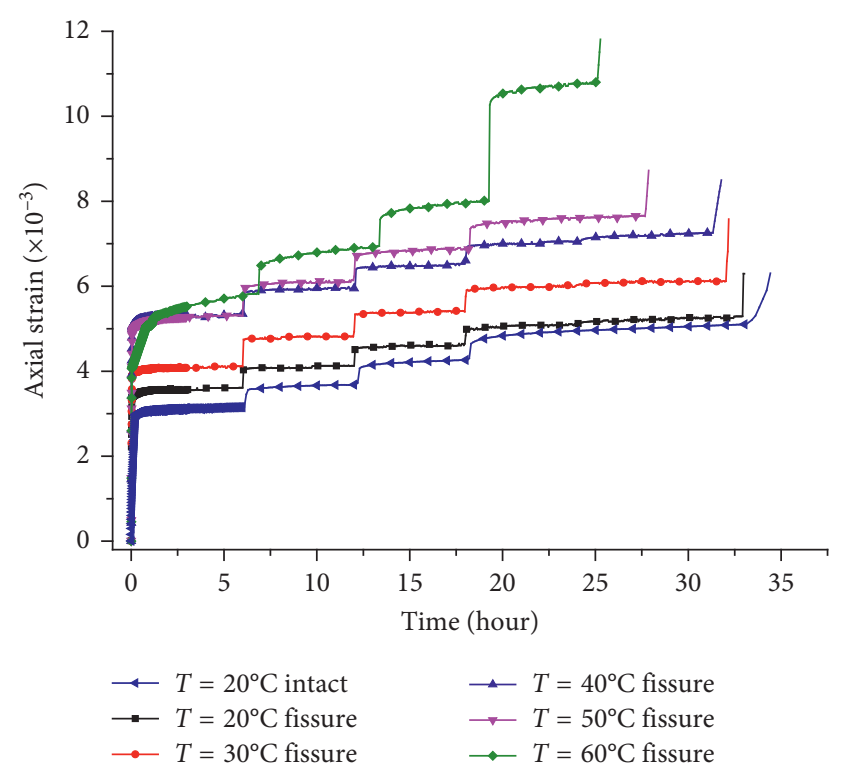

FIGURE 6: Strain-time curves obtained from uniaxial multistage creep experiments for the shale-like material under different temperatures $(\mathrm{T})$.

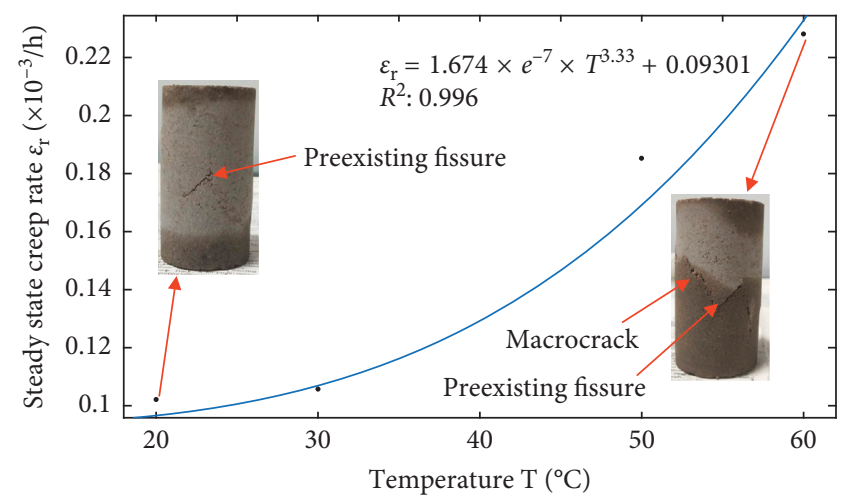

- Experiment data

Figure 7: Steady-state creep rate at different temperatures (confining pressure $=0 \mathrm{MPa}$ ).

temperatures, the steady-state creep rate increases in power function with temperature (correlation coefficient $R^{2}=0.996$ ), which indicates that the steady-state creep rate increases with temperature.
TABLE 4: Creep strain rate of each stage at different temperatures.

\begin{tabular}{lcccc}
\hline $\mathrm{T}\left({ }^{\circ} \mathrm{C}\right)$ & \multicolumn{4}{c}{ Creep strain rate $\left(\times 10^{-3} / \mathrm{h}\right)$} \\
& First stage & Second stage & Third stage & Fourth stage \\
\hline 20 & 0.22 & 0.07 & 0.05 & 0.11 \\
30 & 0.23 & 0.05 & 0.07 & 0.11 \\
40 & 0.24 & 0.07 & 0.07 & 0.12 \\
50 & 0.26 & 0.13 & 0.13 & 0.14 \\
60 & 0.27 & 0.19 & 0.25 & 0.21 \\
\hline
\end{tabular}

\subsection{Triaxial Creep Experiment under Different Confining} Pressures at $20^{\circ} \mathrm{C}$. Triaxial creep experiments are performed on shale-like material in order to investigate the influence of confining pressure. Figure 8 confirms that the creep curves at different confining pressures are qualitatively similar to those obtained from the conventional creep experiment [26]. And, the creep is more obvious at high confining pressure than at low confining pressure: the reason is the higher the confining pressure, the bigger the differential stress. And, the creep strain rate is strongly dependent on the level of the differential stress [28]. The failure mode of shale-like material transforms into plastic mode form brittle mode due to the increase of confining pressure $[29,30]$. The creep strain rate in each stage increases with time; for example, at a constant confining pressure of $5 \mathrm{MPa}$, the creep strain rates in each stage are $1.13 \times 10^{-3} / \mathrm{h}, 1.16 \times 10^{-3} / \mathrm{h}, 1.23 \times 10^{-3} / \mathrm{h}$, $1.96 \times 10^{-3} / \mathrm{h}$, respectively. The increment of the creep strain rate is bit in the first three stages, whereas the increment is obvious in the fourth stage when confining pressure below $5 \mathrm{MPa}$. The reason can be attributable to the closure of preexisting fissure, which accelerates the deformation of the specimen [31]. Huge creep strain occurs at the confining pressure of $7 \mathrm{MPa}$ : the reason can be attributed to the transformation of failure mode.

The creep strain rate of each creep stage at different confining pressures is shown in Figure 9. The creep strain rates are not much different in four creep stages at confining pressure of $1 \mathrm{MPa}$, which indicates that the generation and propagation of microcrack inside the specimen is limited because of the influence of confining pressure; therefore, the preexisting fissure closes uniformly at four creep stages. The creep strain rate is stable in the first three stages, whereas acceleration occurs at the fourth stage under confining pressure of 3 and $5 \mathrm{MPa}$. The reason can be attributed to the decrease of microcrack propagation inside the specimen under the effect of lateral pressure [21], which 


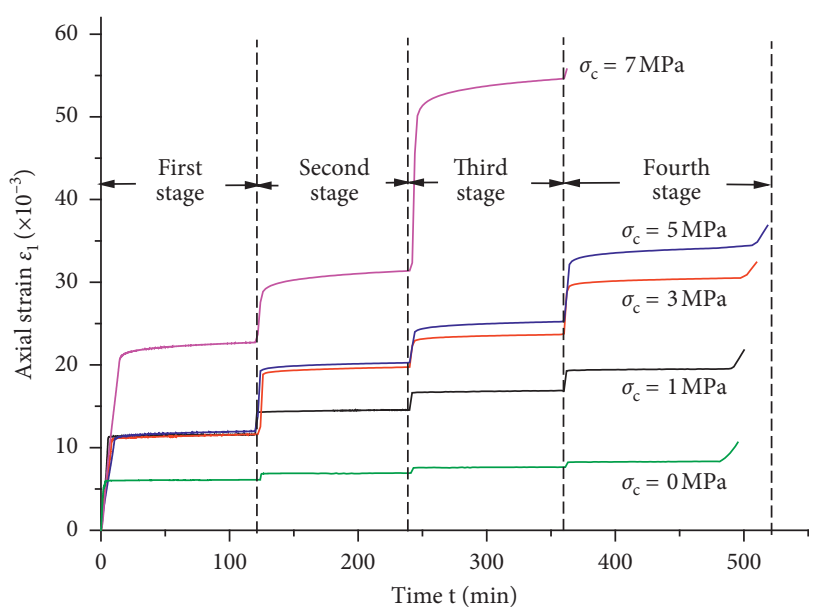

FIgURE 8: Strain-time curves obtained from triaxial multistage creep experiments for the shale-like material under different confining pressures $\left(\mathrm{T}=20^{\circ} \mathrm{C}\right)$.

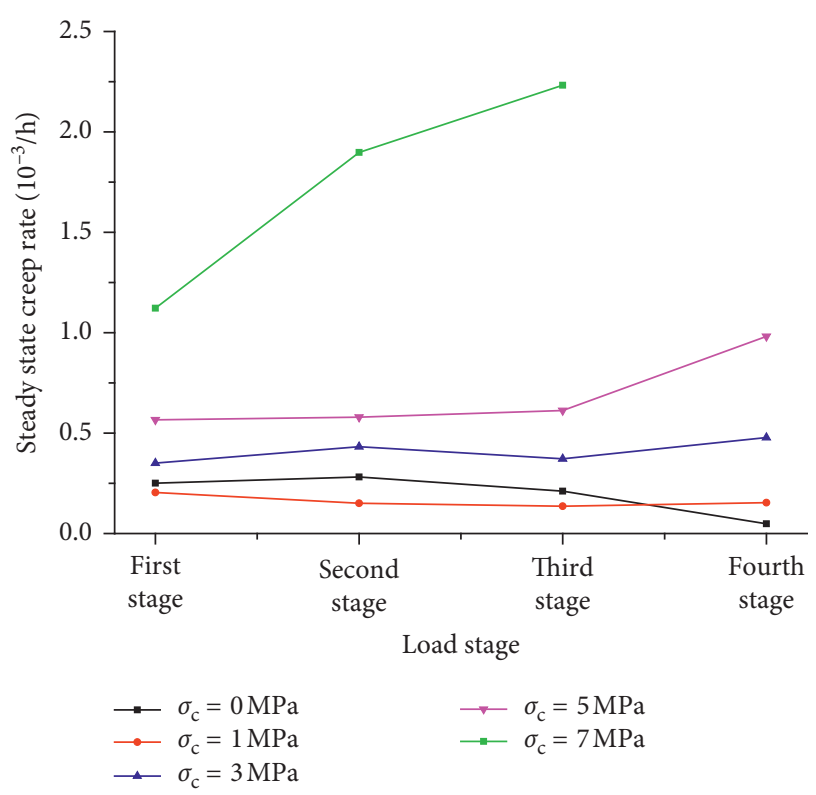

Figure 9: Creep strain rate of each creep stage at different confining pressures.

results in the preexisting fissure that does not close in the first three creep stages. The preexisting fissure closes with the increase of axial stress in the fourth creep stages, which contributes to the acceleration of the creep strain rate in the fourth creep stage. The creep strain rate is obviously higher at confining pressure of $7 \mathrm{MPa}$ than that of other results at confining pressure of $0 \sim 5 \mathrm{MPa}$; this is due to the transformation of failure mode. The failure mode of soft rock transforms from brittle failure to plastic failure with the increase of confining pressure, and then, large deformation occurs.

The steady-state creep rates at different confining pressures are shown in Figure 10. The steady-state creep rate increases with confining pressure. The steady-state creep rates are not much different at 0 and $1 \mathrm{MPa}$, which confirms that confining pressure of $1 \mathrm{MPa}$ has little

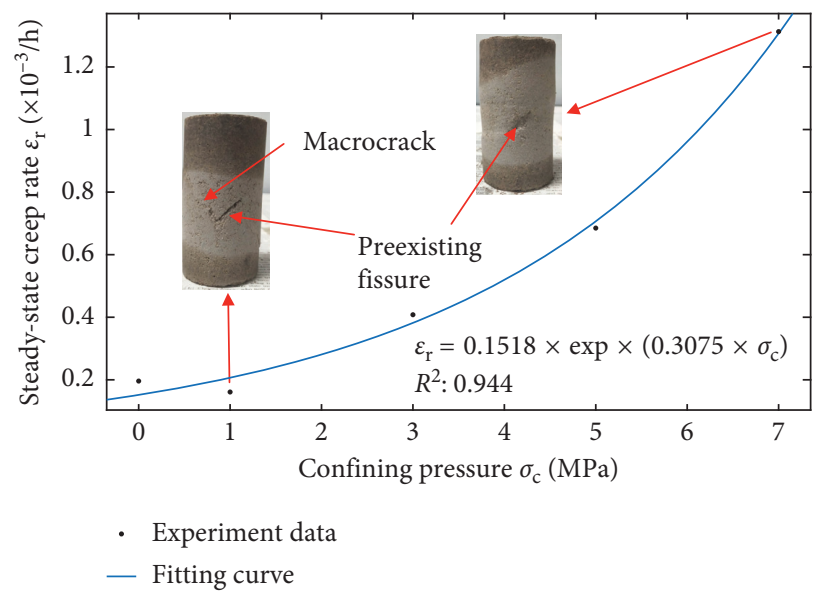

FIGURE 10: Steady-state creep rate at different confining pressures $\left(\mathrm{T}=20^{\circ} \mathrm{C}\right)$.

influence on the steady-state creep rate. However, the influence, which increases the confining pressure on the steady-state creep rate, is enhanced when confining pressure is between 3 and $7 \mathrm{MPa}$. Figure 10 shows the fitted curve of the steady-state creep rate at different confining pressures, which indicates that the steady-state creep rate increases exponentially with confining pressure at $20^{\circ} \mathrm{C}$ (correlation coefficient $R^{2}=0.994$ ). Therefore, the creep rates increase with confining pressure under the same level of loading grade. The damaged specimens are shown in Figure 10. The closure of preexisting fissure is incomplete at confining pressure of $1 \mathrm{MPa}$, whereas it is complete at confining pressure of $7 \mathrm{MPa}$. The reason of this phenomenon, which is the specimen failure with a small axial deformation when the confining pressure is $1 \mathrm{MPa}$ whereas a big axial deformation when the confining pressure is 7 $\mathrm{MPa}$, can be attributed to the difference in the failure mode.

\subsection{Triaxial Creep Experiment under Different Confining} Pressures at $60^{\circ} \mathrm{C}$. The coupling investigation of temperature and confining pressure is carried out on the shale-like material with preexisting fissure. The strain-time curves are shown in Figure 11. The curves are similar to the curves from the experiments at $20^{\circ} \mathrm{C}$. However, the creep strain rate increases with temperature significantly at the same confining pressure when confining pressure is below $3 \mathrm{MPa}$. For example, when the values of confining pressure are 1 and $3 \mathrm{MPa}$, the creep rates are $0.16 \times 10^{-3} / \mathrm{h}$ and $0.41 \times 10^{-3} / \mathrm{h}$ at $20^{\circ} \mathrm{C}$, respectively, whereas when temperature rises to $60^{\circ} \mathrm{C}$, the values are $0.36 \times 10^{-3} / \mathrm{h}$ and $0.50 \times 10^{-3} / \mathrm{h}$, respectively. The results confirm that the steady-state creep rate increases with temperature under the coupling effect of temperature and confining pressure. Compared with the result from Section 3.1, temperature has less significant influence on the creep strain rate under the coupling influence of temperature and confining pressure.

The creep strain rates of each creep stage at $60^{\circ} \mathrm{C}$ are shown in Table 5. The creep strain rates at all confining pressures decreased at first, and then increased. The rates are bigger in the first and the fourth stages but smaller in the 


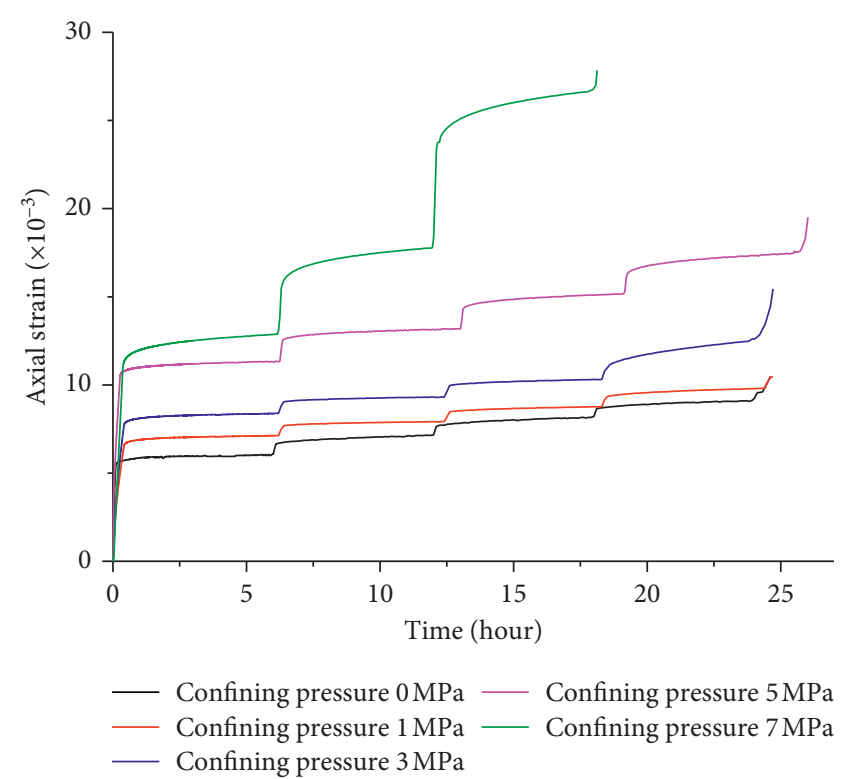

FIgURE 11: Strain-time curves obtained from triaxial multistage creep experiments for the shale-like material under different confining pressures $\left(\mathrm{T}=60^{\circ} \mathrm{C}\right)$.

TABle 5: Creep strain rate of each stage at different confining pressures.

\begin{tabular}{lcccc}
\hline \multirow{2}{*}{$\sigma_{\mathrm{c}}(\mathrm{MPa})$} & \multicolumn{4}{c}{ Creep strain rate $\left(\times 10^{-3} / \mathrm{h}\right)$} \\
& First stage & Second stage & Third stage & Fourth stage \\
\hline 0 & 0.27 & 0.24 & 0.26 & 0.29 \\
1 & 0.32 & 0.28 & 0.22 & 0.60 \\
3 & 0.38 & 0.31 & 0.35 & 0.95 \\
5 & 0.42 & 0.35 & 0.45 & 0.89 \\
7 & 0.48 & 0.50 & 1.21 & - \\
\hline
\end{tabular}

second and the third stages. With the influence of temperature and the closure of preexisting fissure, the generation of microcracks is pronounced in the first stage, which contributed that the creep strain rate is faster in the first stage. The new microcracks decreases in the second and the third stages because the temperature is stable and the influence of preexisting is reduced. Therefore, the creep strain rates are small in the second and the third stages. The creep strain rate increases in the fourth stage; this is because the load in the fourth stage has reached the long-term strength of the shale-like material, and then the acceleration creep phase occurs.

The fitting curve of the shale-like material under different confining pressures at $60^{\circ} \mathrm{C}$ is shown in Figure 12 . We can find that the tendency of the fitting curve at $60^{\circ} \mathrm{C}$ is similar to that at $20^{\circ} \mathrm{C}$; that is, the average creep strain rate increases with confining pressure in an exponential way (correlation coefficient $R^{2}=0.951$ ). However, the steadystate creep rate at $60^{\circ} \mathrm{C}$ is bigger than that at $20^{\circ} \mathrm{C}$ under a constant confining pressure, which can be attributed to the increasing temperature that produced more microcracks. The closure of preexisting fissure is incomplete at confining pressure of $1 \mathrm{MPa}$, whereas it is complete at $7 \mathrm{MPa}$, which is similar to the result from Section 3.2.

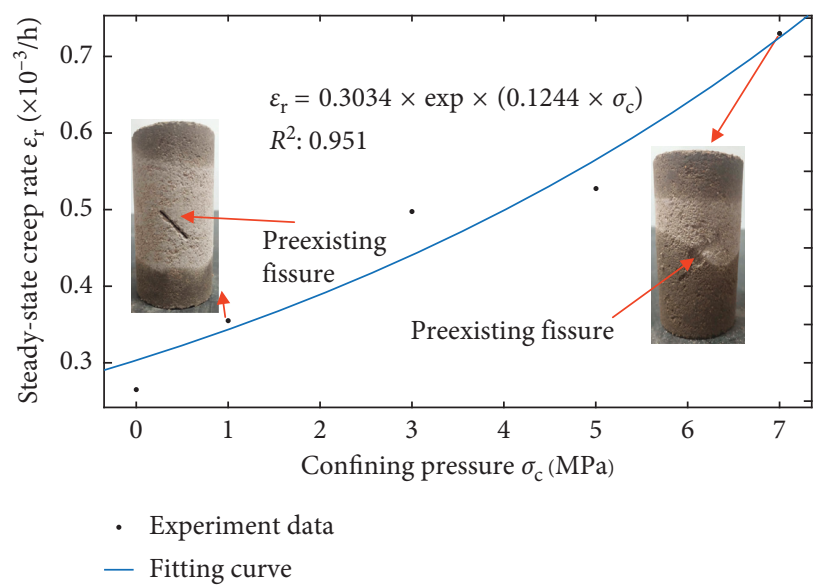

Figure 12: Steady-state creep rate at different confining pressures $\left(\mathrm{T}=60^{\circ} \mathrm{C}\right)$.

3.4. Creep Mechanism Analysis Based on SEM. In order to explain how the temperature and confining pressure influence the process of creep, SEM (scanning electron microscope) was used to observe the fracture surface of the specimen, and four representative pictures are shown in Figure 13.

(1) The influence of temperature: By comparing the Figures 13(a) and 13(b), there were more microcracks in the specimen as the temperature increased. We found from the results of SEM that elevated temperature resulted in the initiation and propagation of microcracks, and the higher the temperature was, the more and larger the microcracks were. The reason of the initiation of microcracks was the separation of sand (aggregate) and cement (cementing agent). The expansion factor of each component was different, which resulted in the different expansion degree of different components. And, the maldistribution of the component resulted in the difference of expansion degree at different parts of the specimen. The separation occurred with elevated temperature, and then new microcracks generated. So we found that the creep rate increased with temperature in our experiments.

(2) The influence of confining pressure: By comparing Figures 13(a) and 13(c), the pores and microcracks reduced due to the influence of confining pressure, which resulted in the compaction of the inner space. Inner (see in Figure 13(c)) and the surface (see in Figure 10) cracks of the specimen decreased significantly with the influence of confining pressure. The failure mode of the specimen had been transformed from brittle failure to plastic failure with the effect of confining pressure, which resulted in the creep rate accelerated at the same loading grade.

(3) The combined influence of temperature and confining pressure: By comparing Figures 13(a)-13(d), compared with the microcracks in Figure 13(a), the microcracks were less and smaller in size in 


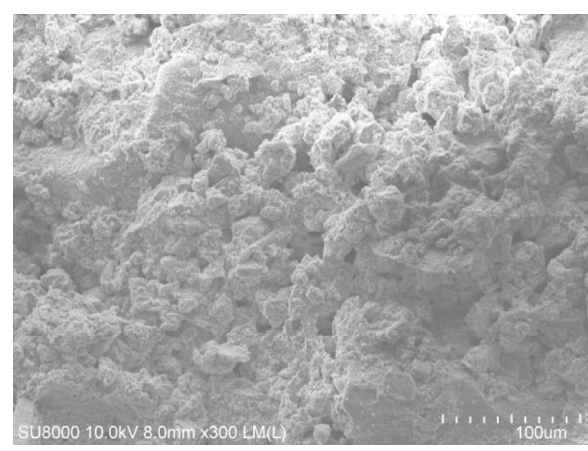

(a)

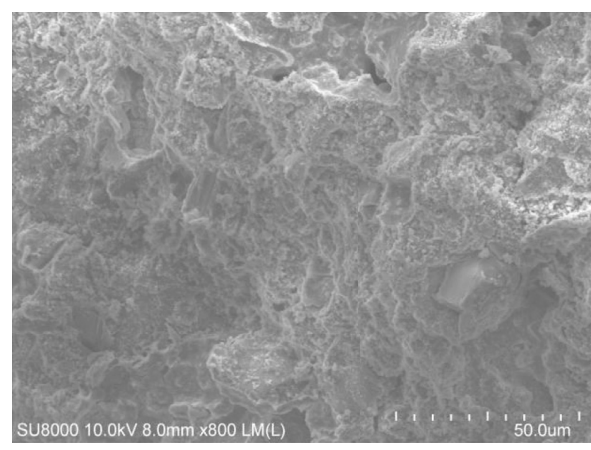

(c)

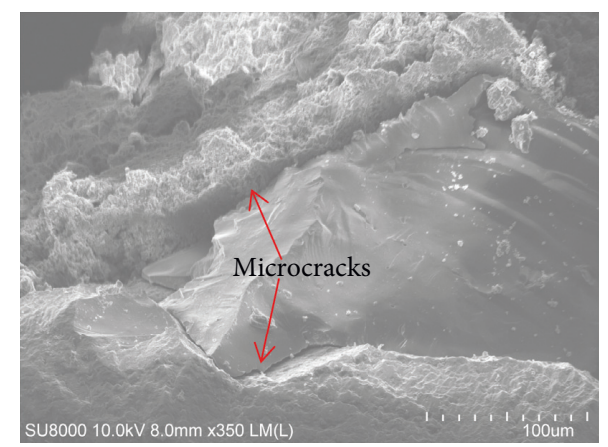

(b)

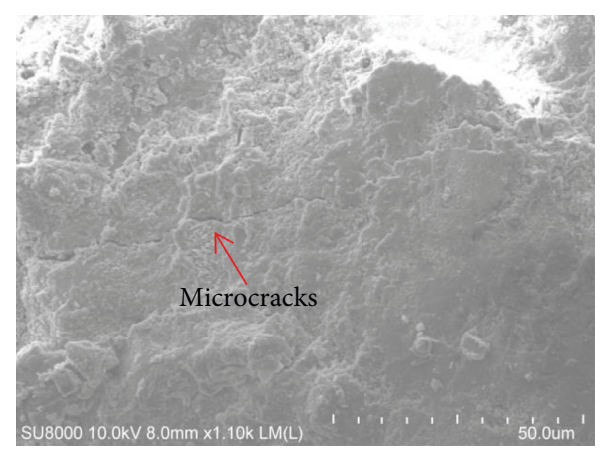

(d)

FIGURE 13: SEM results of cracks surface of shale-like material after creep experiments. (a) Room temperature, confining pressure 0 MPa. (b) Temperature $60^{\circ} \mathrm{C}$, confining pressure $0 \mathrm{MPa}$. (c) Room temperature, confining pressure $7 \mathrm{MPa}$. (d) Temperature $60^{\circ} \mathrm{C}$, confining pressure $7 \mathrm{MPa}$.

Figure 13(d). This was because the separation of sand and the cement was restricted by confining pressure, so the initiation and propagation of microcracks reduced. The initiation and propagation of microcracks were influenced simultaneously by temperature and confining pressure when both of them applied to the specimen. The initiation and propagation of microcracks would be restricted by confining pressure, whereas they would be promoted by temperature, but the influence of confining pressure was more significant than that of temperature. So the temperature had little influence on creep when both confining pressure and temperature applied to the specimen.

(4) Influence of preexisting fissure: The axial deformation increased due to the closure of fissure. And, the cracks on the surface appeared from the tips of the preexisting fissure, which was due to the stress concentration on the tip. The cracks around the tips increased with elevated temperature, which is because the stress concentration was enhanced by temperature. However, the cracks around the tips decreased with confining pressure, which is because the initiation and propagation of microcracks were restricted and stress concentration was weakened. And, the closure of preexisting fissure would promote the creep rate distinctly in uniaxial creep test but indistinctly in triaxial creep test.

\section{Conclusions}

Creep experiments were carried out on shale-like material with preexisting fissure under different temperatures and confining pressures, and we investigated the influence of preexisting fissure, temperature, and confining pressure on creep characteristics of shale-like material. The main conclusions were summarized as follows:

(1) In uniaxial creep experiments, we found the influence of temperature on the creep characteristics is based on the generation and propagation of microcracks due to elevated temperature. Elevated temperature promoted the generation of microcracks inside the specimen. The creep strain rate increased with temperature; moreover, the generation and propagation of microcrack were pronounced at $60^{\circ} \mathrm{C}$ and least at $20 \sim 50^{\circ} \mathrm{C}$.

(2) In triaxial creep experiments $\left(20^{\circ} \mathrm{C}\right)$, we found that the creep strain rate of shale-like material increased with confining pressure under a certain loading grade. The confining pressure of $1 \mathrm{MPa}$ had little influence on the creep strain rate, whereas the creep strain rate increased with confining pressure at 3 7 MPa. The failure mode transformed from brittle failure to plastic failure at confining pressure of $7 \mathrm{MPa}$ and the steady-state creep rates increased with confining pressure at certain loading grade. 
(3) Triaxial creep experiments were carried out on shalelike material at different confining pressures and at the same temperature $\left(60^{\circ} \mathrm{C}\right)$. Compared with the results from uniaxial creep experiments and triaxial creep experiments at $20^{\circ} \mathrm{C}$, we found the results at $60^{\circ} \mathrm{C}$ were different from the results from those two experiments; it was less significant that steady-state creep rates increased with temperature under the coupling influence of temperature and confining pressure. The generation of microcrack was conspicuous in the first stage and unconspicuous in the rest of the stages.

(4) The main influence of preexisting fissure on creep characteristics reflected in the increase of the creep strain rate, where the creep strain rate would be accelerated when preexisting fissure closed. This phenomenon occurred in the first creep stage of uniaxial creep experiments and in the fourth stage of triaxial experiments at confining pressure. The closure of preexisting fissure is incomplete at lower confining pressure but complete at higher confining pressure.

(5) The fitting curves of the steady-state creep rate with temperature and confining pressure were obtained, the steady-state creep rate increased in a power function way with temperature and increased exponentially with confining pressure at both $20^{\circ} \mathrm{C}$ and $60^{\circ} \mathrm{C}$, and the correlation coefficients ( $R$-square) were $0.996,0.994$, and 951, respectively. The effect of temperature on the steady-state creep rate was slight in axial creep experiment, whereas it was powerful in triaxial creep experiments.

\section{Data Availability}

The data used to support the findings of this study are available from the corresponding author upon request.

\section{Conflicts of Interest}

The authors declare that there are no conflicts of interest regarding the publication of this article.

\section{Acknowledgments}

This article was funded by the project (no. 51674149) supported by National Natural Science Foundation of China. The authors wish to acknowledge the support.

\section{References}

[1] X. Heping, G. Feng, and J. Yang, "Research and development of rock mechanics ground engineering," Chinese Journal of Rock Mechanics and Engineering, vol. 34, no. 11, pp. 21612178, 2015, in Chinese.

[2] L. Chen, J. Liu, C. Wang, J. Liu, and J. Wang, "Experimental investigation on the creep behaviour of Beishan granite under different temperature and stress conditions," European Journal of Environmental and Civil Engineering, vol. 19, no. 1, pp. s43-s53, 2015.
[3] E. Rybacki, J. Herrmann, R. Wirth, and G. Dresen, "Creep of posidonia shale at elevated pressure and temperature," Rock Mechanics and Rock Engineering, vol. 50, no. 12, pp. 31213140, 2017.

[4] Y. Lu and L. Wang, "Effect of water and temperature on shortterm and creep mechanical behaviors of coal measures mudstone," Environmental Earth Sciences, vol. 76, no. 17, pp. 1-15, 2017.

[5] M. J. Heap, P. Baud, and P. G. Meredith, "Influence of temperature on brittle creep in sandstones," Geophysical Research Letters, vol. 36, pp. 1-6, 2009.

[6] Y. Nara, M. Takada, T. Igarashi, N. Hiroyoshi, and K. Kaneko, "Subcritical crack growth in rocks in an aqueous environment," Exploration Geophysics, vol. 40, no. 1, pp. 163-171, 2009.

[7] Y. Nara, M. Takada, D. Mori, H. Owada, T. Yoneda, and K. Kaneko, "Subcritical crack growth and long-term strength in rock and cementitious material," International Journal of Fracture, vol. 164, no. 1, pp. 57-71, 2010.

[8] B. K. Atkinson, "Stress corrosion and the rate-dependent tensile failure of a fine-grained quartz rock," Tectonophysics, vol. 65, no. 3-4, pp. 281-290, 1980.

[9] P. G. Meredith and B. K. Atkinson, "Stress corrosion and acoustic emission during tensile crack propagation in Whin Sill dolerite and other basic rocks," Geophysical Journal International, vol. 75, no. 1, pp. 1-21, 1983.

[10] R. L. Kranz, W. J. Harris, and N. L. Carter, "Static fatigue of granite at $200^{\circ} \mathrm{C}$," Geophysical Research Letters, vol. 9, no. 1, pp. 1-4, 1982.

[11] G. Chen, T. Li, G. Li, C. A. Qin, and Y. He, "Influence of temperature on the brittle failure of granite in deep tunnels determined from triaxial unloading tests," European Journal of Environmental and Civil Engineering, vol. 22, no. 1, pp. s269-s285, 2018.

[12] H. Zhang, Z. Wang, Y. Zheng, P. Duan, and S. Ding, "Study on tri-axial creep experiment and constitutive relation of different rock salt," Safety Science, vol. 50, no. 4, pp. 801-805, 2012.

[13] B. Mishra and P. Verma, "Uniaxial and triaxial single and multistage creep tests on coal-measure shale rocks," International Journal of Coal Geology, vol. 137, pp. 55-65, 2015.

[14] Z. B. Liu, S. Y. Xie, J. F. Shao, and N. Conil, "Multi-step triaxial compressive creep behaviour and induced gas permeability change of clay-rich rock," Géotechnique, vol. 68, no. 4, pp. 281-289, 2018.

[15] Y. Zhang, J. Shao, W. Xu, and Y. Jia, "Time-dependent behavior of cataclastic rocks in a multi-loading triaxial creep test," Rock Mechanics and Rock Engineering, vol. 49, no. 9, pp. 3793-3803, 2016.

[16] Y. Zhang, X. D. Zhang, J. F. Shao, Y. Jia, and Y. L. Wang, "Elastoplastic modelling the creep behaviour of cataclastic rock under multi-stage deviatoric stress," European Journal of Environmental and Civil Engineering, vol. 22, no. 6, pp. 650-665, 2018.

[17] Z. L. Zhang, W. Y. Xu, W. Wang, and R. B. Wang, “Triaxial creep tests of rock from the compressive zone of dam foundation in Xiangjiaba Hydropower Station," International Journal of Rock Mechanics and Mining Sciences, vol. 50, pp. 133-139, 2012.

[18] S. Nadimi, K. Shahriar, M. Sharifzadeh, and P. Moarefvand, "Triaxial creep tests and back analysis of time-dependent behavior of Siah Bisheh cavern by 3-Dimensional Distinct Element Method," Tunnelling and Underground Space Technology, vol. 26, no. 1, pp. 155-162, 2011. 
[19] Y. Chao, H. Da, C. Rui et al., "Triaxial unloading creep tests on rock mass with an open and penetrating flaw," Rock and Soil Mechanics, vol. 39, no. 1, pp. 53-62, 2018, in Chinese.

[20] P. Zhipeng, F. Xiating, S. Fanglin et al., "Study of anisitropic creep behavior of fractured granite," Chinese Journal of Rock Mechanics and Engineering, vol. 30, no. 1, pp. 36-44, 2011, in Chinese.

[21] N. Brantut, M. J. Heap, P. G. Meredith, and P. Baud, "Timedependent cracking and brittle creep in crustal rocks: a review," Journal of Structural Geology, vol. 52, no. 5, pp. 17-43, 2013.

[22] M. J. Heap, P. Baud, P. G. Meredith, S. Vinciguerra, A. F. Bell, and I. G. Main, "Brittle creep in basalt and its application to time-dependent volcano deformation," Earth and Planetary Science Letters, vol. 307, no. 1-2, pp. 71-82, 2011.

[23] W. Yongyan, Z. Jinlong, and Z. Yubiao, "The experimental investigation of single fracture rock strength characteristics and creep model by experiment," Science Technology and Engineering, vol. 18, no. 18, pp. 94-100, 2018.

[24] Y. C. Wang and Y. Y. Wang, "Experimental research on creep behavior of soft rock under complex enviorment," Journal of Shandong University of Science and Techology (Natural Science), vol. 33, no. 3, pp. 54-59, 2014, in Chinese.

[25] Ministry of Housing and Urban-Rural Construction of the People's Republic of China and General Administration of Quality Supervision, Inspection and Quarantine of the People's Republic of China, Standard for Test Methods of Engineering Rock Mass, China Planing Press, Beijing, China, 2013, in Chinese.

[26] M. J. Heap, P. Baud, P. G. Meredith, A. F. Bell, and I. G. Main, "Time-dependent brittle creep in Darley Dale sandstone," Journal of Geophysical Research, vol. 114, no. B7, pp. 1-22, 2009.

[27] P. W. J. Glover, P. Baud, M. Darot et al., “ $\alpha / \beta$ phase transition in quartz monitored using acoustic emissions," Geophysical Journal International, vol. 120, no. 3, pp. 775-782, 1995.

[28] Y. Fujii, T. Kiyama, Y. Ishijima, and J. Kodama, "Circumferential strain behavior during creep tests of brittle rocks," International Journal of Rock Mechanics and Mining Sciences, vol. 36, no. 3, pp. 323-337, 1999.

[29] M. S. Paterson, Experimental Rock Deformation-The Brittle Field, Springer, Berlin, Germany, 2nd edition, 2005.

[30] S.-Q. Yang, Y. Ju, F. Gao, and Y.-L. Gui, "Strength, deformability and $X$-ray micro-CT observations of deeply buried marble under different confining pressures," Rock Mechanics and Rock Engineering, vol. 49, no. 11, pp. 42274244, 2016, in Chinese.

[31] T.-F. Wong, C. David, and W. Zhu, "The transition from brittle faulting to cataclastic flow in porous sandstones: mechanical deformation," Journal of Geophysical Research: Solid Earth, vol. 102, no. B2, pp. 3009-3025, 1997. 


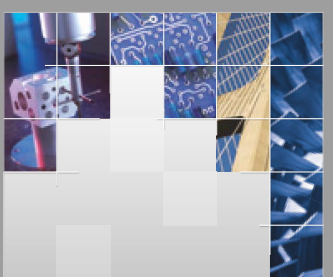

\section{Enfincering}
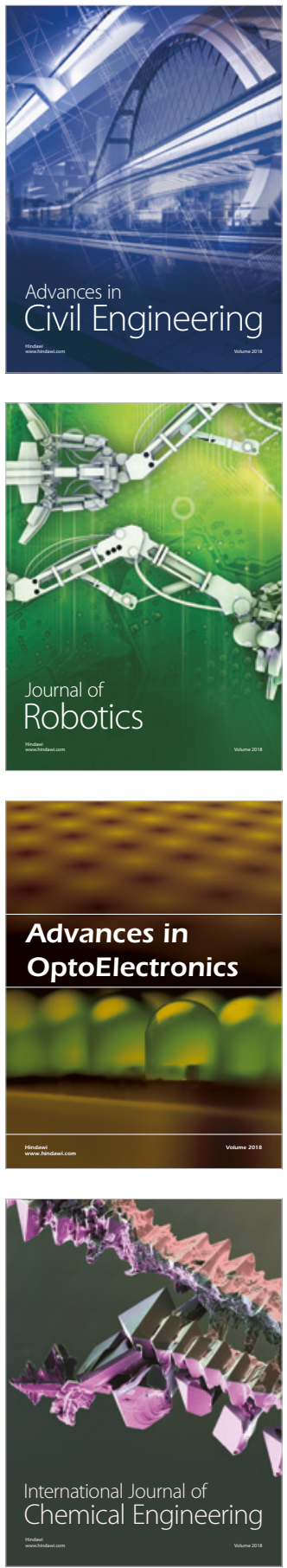

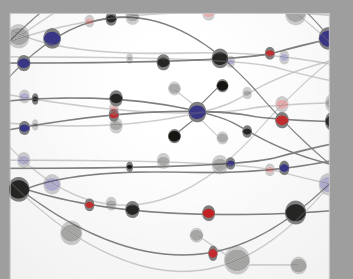

\section{Rotating \\ Machinery}

The Scientific World Journal

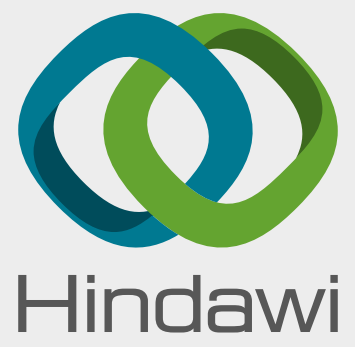

Submit your manuscripts at

www.hindawi.com
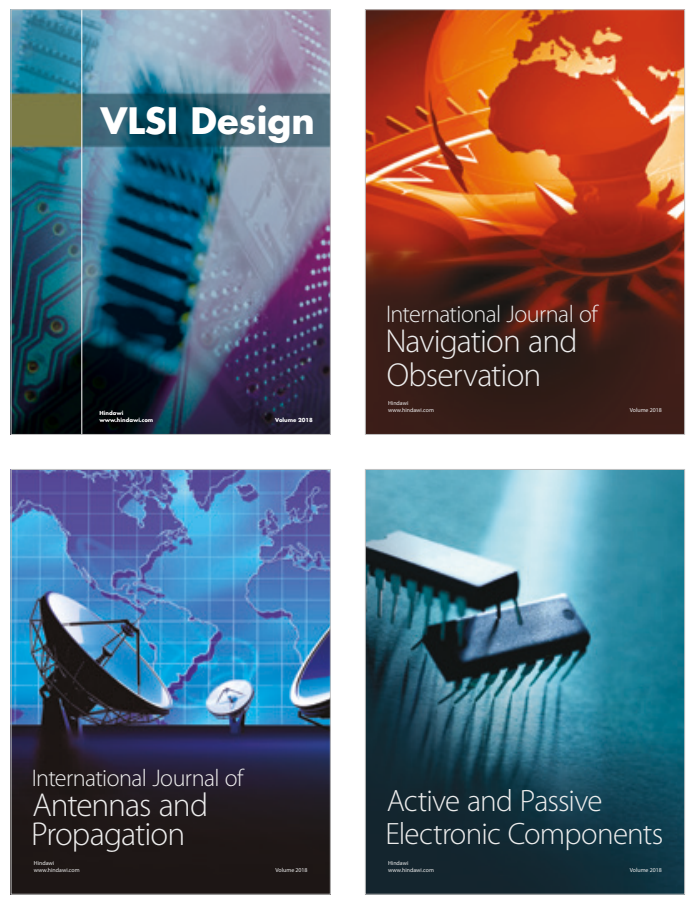
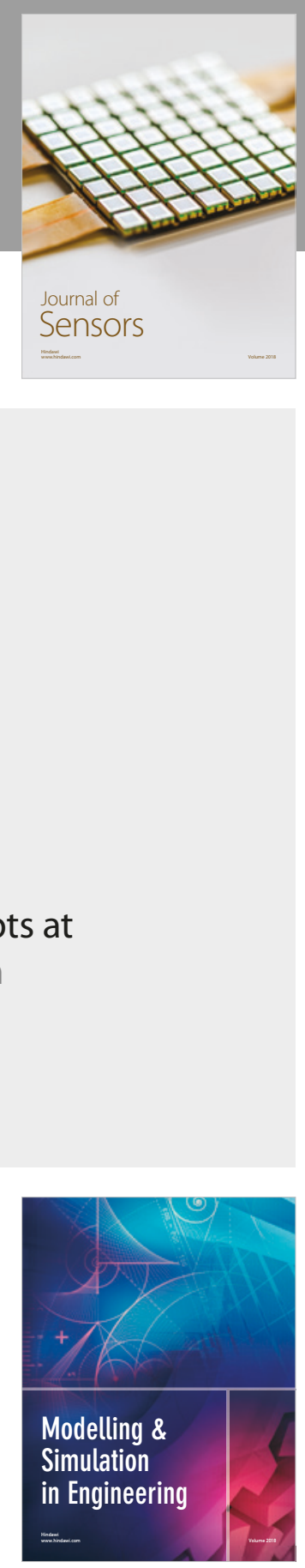

\section{Advances \\ Multimedia}
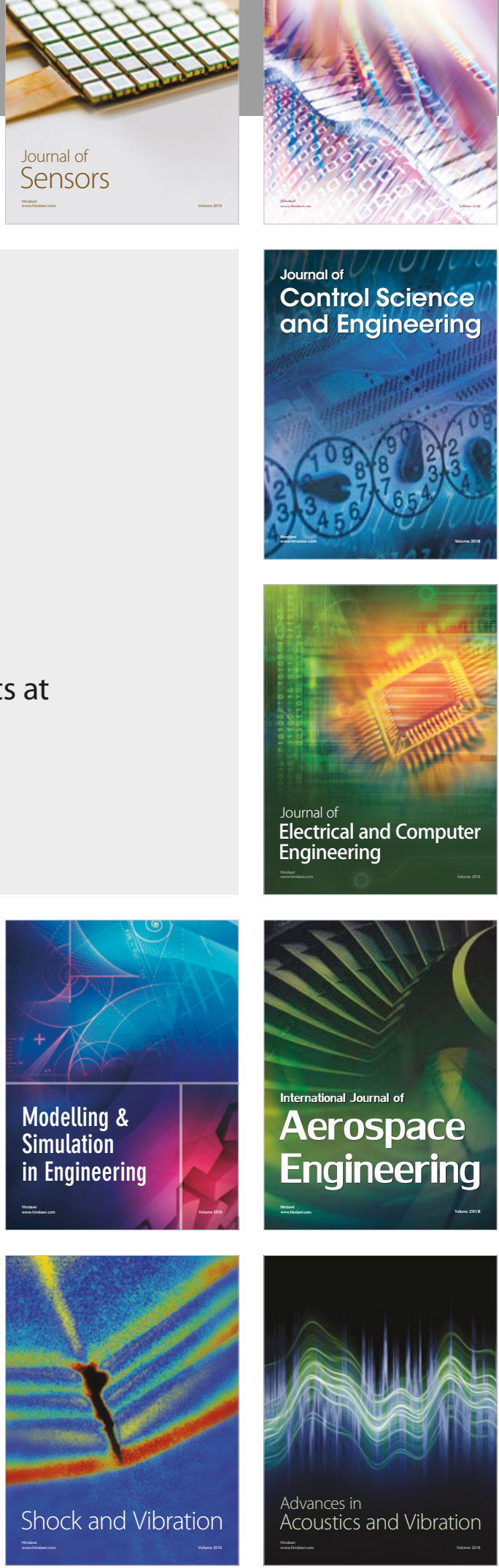